\title{
Politik Hukum Ekonomi Syariah dalam Perkembangan Lembaga Keuangan Syariah di Indonesia
}

\author{
M ul Irawan
}

DATA NASKAH

Masuk: 06 Nopember 2017

Diterima: 08 M ei 2018

Terbit: 1 Juni 2018

KORESPONDEN PENULIS:

Pusat Penelitian dan Pengembangan Hukum dan Peradilan Mahkamah Agung Rl.

Jl. Ahmad Yani Kav. 58-59. Cempaka Putih, Jakarta Pusat

Email: mul_irawan@yahoo.com

\begin{abstract}
Sharia economy has grown rapidly in Indonesia. This is indicated by the increasing number of bank and non-bank that use sharia principles. 0 ne of the alleged supporters of this development is the political economy of sharia law conducted by the government. The problem is on the role of law politic between the sharia financial institutions regulation and the sharia financial institutions development. This research aims to provide an objective picture as well as a recommendation for the strengthening of I slamic politic of law and sharia regulations. This research used normative method, which is a study on regulation, re search result, journal, data and other reference, that will be analyzed by qualitative descriptive method. The results of the study found that the politic of laws and regulations of sharia economy have contributed and established facilities for the development of Islamic financial institutions in Indonesia. The unity of law politic and sharia economic regulation has established public trust and provides opportunities and protection for community, bussiness people, customersand sharia financial institutions.
\end{abstract}

K eywords: political law, economy, sharia finance.

\section{ABSTRAK}

Ekonomi syariah telah berkembang pesat di Indonesia. Hal tersebut ditunjukkan dengan makin banyaknya perbankan dan lembaga keuangan non-bank yang menggunakan prinsip syariah. Salah satu pendukung perkembangan ekonomi syariah adalah politik hukum ekonomi syariah oleh pemerintah. Permasalahannya adalah bagaimana peran politik hukum dalam perkembangan regulasi ekonomi syariah serta perkembangan lembaga keuangan ekonomi syariah itu sendiri. Tujuan dari penelitian ini adalah memberikan gambaran obyektif serta menjadi rekomendasi untuk penguatan politik hukum dan regulasi ekonomi syariah. 
Penelitian ini menggunakan metode yuridis normatif, yaitu penelitian yang mengacu pada peraturan perundang-undangan, hasil penelitian, jurnal, data dan referensi lainnya, yang dianalisis dengan metode deskriptif kualitatif. $\mathrm{H}$ asil penelitian menunjukkan bahwa politik hukum telah berperan dalam pembentukan dan pengembangan regulasi ekonomi syariah, dan telah memberi kontribusi bagi berkembangnya lembaga keuangan syariah di Indonesia. Harmonisasi politik hukum dengan regulasi ekonomi syariah juga telah membentuk kepercayaan sekaligus fasilitas perlindungan bagi masyarakat, pelaku bisnis, nasabah dan lembaga keuangan syariah.

$\mathrm{K}$ ata kunci: politik hukum, ekonomi, keuangan syariah.

\section{PENDAHULUAN}

Lebih dari dua puluh tahun terakhir, lembaga keuangan syariah secara nasional terus berkembang. Berawal dari kelahiran Baitul M aal wat Tamwiil (BM T) tahun 1984, yang dikembangkan mahasiswa ITB di Masjid Salman melalui pembentukan lembaga pembiayaan berdasarkan syari'ah, yang diberdayakan oleh ICM I (Ikatan Cendikiawan M uslim Indonesia). BMT membuka kerjasama dengan lembaga pemberi pinjaman dan peminjam bisnis skala kecil dengan berpegang pada prinsip dasar tata ekonomi dalam agama Islam. BMT terus berkembang dan berproses untuk memajukan perekonomian masyarakat, karena masalah muamalat memang berkembang dari waktu ke waktu. Kelahiran BMT merupakan cikal bakal kelahiran perbankan syariah di Indonesia.

Perbankan Syariah sebagai lembaga keuangan ekonomi syariah pertama di Indonesia baru mulai berdiri pada tahun 1992 yaitu dengan berdirinya Bank M uamalat Indonesia yang hadir tanpa dukungan peraturan perundangan yang memadai. Pada dekade pertama, tidak terjadi perkembangan signifikan pada sektor perbankan syariah ini disebabkan tidak adanya payung hukum dan legalitas kelembagaan yang kuat. Perkembangan yang positif baru terjadi setelah disahkannya Undang-Undang Nomor 10 Tahun 1998 tentang Perubahan atas Undang-Undang Nomor 7 Tahun 1992 tentang Perbankan. Pesatnya perkembangan Bank Syariah tersebut tidak lepas dari keunggulan-keunggulan yang dimiliki dan yang ditawarkan oleh Bank Syariah. Bank Syariah adalah bank yang dalamoperasionalnya mendasarkan pada prinsipprinsip Islam (Muhammad, 2014: 46).

Dalam undang-undang tersebut prinsip syariah secara definitif telah terakomodasi, namun istilah bank syariah dipertegas dengan lahirnya Undang-undang Nomor 21 Tahun 2008 tentang Perbankan Syariah. Seiring perkembangan perbankan syariah yang semakin meningkat, pada sisi lain Lembaga Keuangan Syariah Non Bank juga semakin menunjukkan peningkatan seperti pada Lembaga Asuransi Syariah, Pasar Modal Syariah, Pegadaian Syariah, Dana Pensiun Lembaga Keuangan (DPLK) Syariah, Koperasi Syariah, Perusahaan dengan Prinsip Syariah, Badan Wakaf, Badan Amil Zakat, dan BMT. Lahirnya Undang-Undang Nomor 21 Tahun 2008 tentang Perbankan Syariah menjadikan pijakan hukum bank syariah menjadi cukup jelas dan kuat, baik dari segi kelembagaannya maupun dari segi landasan operasionalnya. Kondisi tersebut tidak lepas dari pengaruh keberadaan hukum dan regulasi yang menjadi pendukungnya.

Secara istilah, politik hukum terkadang juga dikaitkan dengan kebijakan publik (public policy). Kebijakan dapat diartikan sebagai prinsip-prinsip umum yang berfungsi untuk mengarahkan pemerintah dalam mengelola, mengaturatau menyelesaikan urusan-urusan publik, masalah-masalah masyarakat atau bidang-bidang penyusunan peraturan perundang-undangan dan pengaplikasian hukum/peraturan, dengan suatu tujuan yang mengarah pada upaya mewujudkan kesejahteraan atau kemakmuran masyarakat (warga negara) (Neil, et.all., 1975:1). Pada tataran empiris, politik hukum telah digunakan oleh M ahfud MD dalam memahami relasi antara hukum dan politik. M ahfud MD menghadirkan sebuah pendekatan yang berbeda dalam memahami sebuah fenomena hukum, dalam hal ini berbeda dengan pendekatan klasik yang melihat hukum dari sisi yuridis normatif ansich, Mahfud MD melihat hukum dari sisi yuridis sosio politis, yang menghadirkan sistem politik sebagai variabel yang mempengaruhi rumusan dan pelaksanaan hukum. Berdasarkan hasil penelitiannya, Mahfud MD berkesimpulan bahwa suatu proses dan konfigurasi politik rezim tertentu akan signifikan pengaruhnya terhadap suatu produk hukum yang kemudian dilahirkannya. Dalam negara yang konfigurasi politiknya demokratis, produk hukumnya berkarakter 
responsif atau populistik, sedangkan di negara yang konfigurasi politiknya otoriter, produk hukumnya berkarakter ortodoks atau konservatif atau elitis (Mahmodin, 2010:22). Dalam hal ini dipahami bahwa kebutuhan pembangunan hukum harus sejalan dan sesuai dengan kebutuhan masyarakat.

Bila dikaitkan dengan politik hukum ekonomi syariah, hal tersebut menunjukkan bahwa ketersediaan pranata hukum ekonomi syariah adalah kebutuhan mutlak dalam pembangunan kelembagaan ekonomi syariah. Ketersediaan pranata hukum tersebut merupakan bagian upaya dari politik hukum yang berkaitan erat dengan positivikasi hukum. Positivikasi hukum dipahami sebagai upaya memformalkan suatu hukum yang normatif seperti hukum Islam menjadi hukum nasional, sehingga dipahami bahwa hukum Islam positif artinya adalah hukum Islam yang diformalkan menjadi hukum nasional. Ketentuan hukum formal yang mengatur pelaksanaan kegiatan ekonomi syariah di Indonesia adalah segala ketentuan yang telah melalui proses positifikasi oleh negara. Jika suatu hukum ekonomi sudah diformalkan oleh negara maka kekuatan berlakunya bersumber dari negara, sehingga berlaku menyeluruh bagi rakyat Indonesia dan dapat dipaksakan untuk diterapkan dalam kegiatan ekonomi tersebut (Hamid, 2006;92). Lawrence M. Friedman (2009:33) menjelaskan bahwa hukum memberi pengaruh signifikan terhadap kehidupan masyarakat, karena hukum dibentuk untuk mencapai suatu tujuan. Realitas pernyataan tersebut dapat dilihat dalam perjalanan hukum ekonomi syariah di Indonesia. Berbagai studi tentang hubungan hukum dan ekonomi syariah menunjukkan bahwa kemajuan ekonomi syariah tidak akan berhasil tanpa pembangunan hukum yang mendahuluinya, sehingga sangat tepat jika dikatakan bahwa antara sistem hukum dan sistem ekonomi terdapat interaksi dan hubungan saling pengaruhmempengaruhi.

Berdasarkan uraian tersebut, politik hukum dipandang memiliki titik temu yang sinerg is dengan perkembangan lembaga keuangan ekonomi syariah. Sinergi antara politik hukum dengan ekonomi syariah dapat memperkuat eksistensi lembaga keuangan syariah secara sistematik, sehingga pada gilirannya sistem hukum nasional dan sistem ekonomi syariah nasional dapat mewujudkan pembangunan yang berkelanjutan. Peranan politik hukum dalam pengembangan ekonomi syariah harus dilihat secara integral, karena masing-masing unsur bersifat komplementer dan berada dalam suatu hubungan fungsional. Mengingat hal tersebut, maka perlu dilakukan penelitian yang bertujuan untuk memberikan gambaran obyektif tentang politik hukum ekonomi syariah dan perannya terhadap perkembangan lembaga keuangan syariah serta menjadi rekomendasi untuk penguatan politik hukum dan regulasi ekonomi syariah.

\section{RUMUSAN MASALAH}

1. Bagaimana politik hukum ekonomi syariah dalam perkembangan regulasi lembaga keuangan syariah di Indonesia?

2. Bagaimana perkembangan lembaga keuangan syariah di Indonesia?

\section{METODOLOGI PENELITIAN}

Penelitian ini menggunakan metode normatif. Pendekatan normatif adalah pendekatan yang dilakukan berdasarkan bahan hukum utama dengan cara menelaah teori-teori, konsep-konsep, asas-asas hukum serta peraturan perundangundangan yang berhubungan dengan penelitian ini. Pendekatan penelitian dilakukan terhadap perundang-undangan (statute approach), pendekatan historis (historical approach), pendekatan komparatif (comparative approach), dan pendekatan konseptual (conceptual approach). Analisis yang digunakan dalam penelitian ini adalah analisis deskriptif kualitatif, yaitu menguraikan data yang diolah secara rinci ke dalam bentuk kalimat (deskritif). Analisis kualitatif yang dilakukan bertitik tolak dari analisis data yang dalam pendalamannya dilengkapi dengan analisis normatif. Berdasarkan hasil analisis ditarik kesimpulan secara deduktif, yaitu penarikan kesimpulan yang didasarkan pada fakta-fakta yang bersifat umum untuk kemudian ditarik suatu kesimpulan bersifat khusus.

\section{HASIL PENELITIAN DAN ANALISIS \\ A. Politik Hukum Ekonomi Syariah di Indonesia}

Pengertian politik hukum adalah proses pembuatan dan pelaksanaan hukum yang dapat menunjukkan sifat dan arah 
sebuah hukum yang dibangun dan ditegakkan. Dari pengertian tersebut dijelaskan bahwa politik hukum adalah arahan atau garis resmi yang dijadikan dasar pijak dan cara untuk membuat dan melaksanakan hukum dalam rangka mencapai tujuan bangsa dan negara. Politik hukum merupakan upaya menjadikan hukum sebagai proses pencapaian tujuan negara. Politik hukum dapat dikatakan juga sebagai jawaban atas pertanyaan tentang mau diapakan hukum itu dalam perspektif formal kenegaraan guna mencapai tujuan negara. Kendatipun secara yuridis, penerapan hukum ekonomi syariah di Indonesia memiliki dasar yang sangat kuat, sebagaimana dalam ketentuan Pasal 29 UUD 1945 (Mashudi, 2013:97).

Istilah ekonomi syariah telah dikenal secara luas di Indonesia. Ekonomi syariah atau ekonomi Islam adalah sebuah sistem ekonomi yang berbeda dengan sistem kapitalisme dan sosialisme. Ekonomi Islam memiliki kebaikan-kebaikan yang terdapat dalam kedua sistem tersebut dan terbebas dari kelemahan-kelemahan yang ada dalam kedua sistem tersebut. Ekonomi Islam tidak hanya menyiapkan individuindividu sejumlah kemudahan dalam bekerja sama berlandaskan syariah, tetapi juga memberikan pendidikan moral yang tinggi dalam kehidupan (Afzalurrahman, 1996:10). Umar Chapra mendefinisikan ekonomi Islam dengan ilmu yang memberikan kontribusi langsung atau tidak langsung terhadap realisasi kesejahteraan manusia, tetap berkonsentrasi pada aspek alokasi dan distribusi sumber-sumber daya dengan tujuan utama merealisasi maqashid syariah. Sejalan dengan pendapat di atas, Syed Nawab Haider Naqvi dalam bukunya Islam, Economy, and Society mengemukakan bahwa ekonomi Islam merupakan sistem buatan manusia sebagaimana sistem ekonomi lainnya. Pandangan ini lebih menekankan pada aspek empiris dari ekonomi Islam yang dapat diuji baik secara teoritismaupun praktisnya (Hamid, 2006: 68).

Dari berbagai uraian di atas dapat disimpulkan bahwa politik hukum dalam proses positifikasi hukum ekonomi syariah di Indonesia dapat dipahami sebagai arah, cara, serta kebijakan dari pemerintah dalam upaya memformalkan hukum-hukum yang berkaitan dengan ekonomi syariah di Indonesia. Secara rinci kilasan politik hukum dalam bidang ekonomi syariah ini dapat dipetakan sebagai berikut:
1. Lahirnya Undang-Undang Nomor 19 tahun 2008 tentang Surat Berharga Syariah Negara (SBSN), yang disahkan pada 7 M ei 2008. Undang-Undang ini bertujuan untuk membiayai Anggaran Pendapatan dan Belanja Negara yang selalu defisit, termasuk juga untuk pembiayaan proyek. Hal tersebut menunjukkan dukungan pemerintah untuk mendanai APBN dengan instrumen keuangan syariah. Political will pemerintah dengan mengesahkan UU SBSN terbukti telah mendorong perkembangan sukuk global dengan sangat pesat (Anshori, 2008: 132137).

2. Lahimya Undang-Undang Nomor 21 Tahun 2008 tentang Perbankan Syariah, pada tanggal 17 Juni 2008. Undangundang ini makin menguatkan eksistensi perbankan syariah di Indonesia dan juga dapat makin memacu peningkatan peran dan kontribusi perbankan syariah dalam mengentaskan kemiskinan (poverty alleviation), meningkatkan kesejahteraan masyarakat dan membuka lapangan kerja serta mendorong pembangunan nasional (Ali, 2008: 16).

3. Pendirian Bank Syariah oleh BUMN. Hal tersebut dipandang sebagai bukti nyata dari politik ekonomi syariah yang diperankan oleh pemerintah dalam sektor industri perbankan. Beberapa bank BUM N mendirikan perbankan syariah yang dikenal dengan istilah dual banking system.

4. Lahimya Undang-Undang Nomor 41 Tahun 2004 tentang Wakaf. Pemerintah juga telah menetapkan Peraturan Pemerintah Nomor 42 Tahun 2006 tentang Pelaksanaan Undang-Undang Nomor 41 tahun 2004, ditambah dengan Keputusan Menteri Keuangan Nomor 4 Tahun 2009 tentang Administrasi Wakaf Uang.

5. Berdirinya Dewan Syariah Nasional Majelis Ulama Indonesia (DSN MUI). MUI sebagai lembaga yang memiliki kewenangan dalam bidang keagamaan yang berhubungan dengan kepentingan umat Islam Indonesia membentuk suatu dewan syariah yang berskala nasional yang bernama Dewan Syariah Nasional (DSN) pada tanggal 10 Februari 1999 sesuai dengan Surat Keputusan (SK) MUI Nomor kep754/MUI/II/1999.

6. Lahimya Undang-Undang Nomor 38 Tahun 1999 tentang Zakat. Saat ini zakat yang terkumpul baru mencapai 1 
Triliun rupiah pertahun, padahal potensi zakat yang dapat dikumpulkan secara nasional bisa mencapai 39 triliun rupiah per tahun.

7. Lahirnya Undang-Undang Nomor 3 Tahun 2006. Diundangkannya Undang-Undang Nomor 3 Tahun 2006 tentang Perubahan atas Undang-Undang Nomor 7 Tahun 1989 tentang Peradilan Agama telah memberikan arah baru bagi kompetensi Peradilan Agama untuk menangani, memutus, dan menyelesaikan perkara di tingkat pertama antara orang-orang yang beragama Islam di bidang ekonomi syariah. Amandemen ini dimaksudkan untuk memenuhi kebutuhan hukum masyarakat, terutama setelah tumbuh dan berkembangnya praktik ekonomi Islam di Indonesia.

8. Terbitnya KHES (Kompilasi Hukum Ekonomi Syariah). Penyusunan (KHES) yang dikoordinatori oleh Mahkamah Agung (MA) Rl yang kemudian dilegalkan dalam bentuk Peraturan Mahkamah Agung (PERM A) 02 Tahun 2008 merupakan respon terhadap perkembangan baru dalam kajian dan praktik ekonomi Islam di Indonesia. Kehadiran KHES merupakan bagian upaya positifisasi hukum perdata Islam dalam sistem hukum nasional, mengingat praktik ekonomi syariah sudah semakin semarak melalui berbagai Lembaga Keuangan Syariah.

9. Lahirnya Peraturan Pemerintah Nomor 39 Tahun 2008 tentang Perubahan Kedua atas Peraturan Pemerintah Nomor 73 Tahun 1992 tentang Penyelenggaraan Usaha Perasuransian. Walaupun pemerintah belum mengundangkan secara khusus tentang asuransi Syariah, akan tetapi Peraturan Pemerintah Nomor 39 tersebut menunjukkan keberpihakan pemerintah terhadap pengembangan industri asuransi syariah sebagai bagian politik ekonomi Islamnya.

10.Didirikannya Direktorat pembiayaan Syariah di Departemen Keuangan (Direktorat Pembiayaan Syariah, Direktorat Jenderal Pengelolaan Utang Departemen Keuangan RI) merupakan direktorat yang melaksanakan amanah Undang-Undang Nomor 19/2008 tentang SBSN, sehingga lahir berbagai jenis sukuk negara di antaranya sukuk ritel dan korporasi.

Lahirnya peraturan dan perundang-undangan tersebut telah menandai era baru perbankan syariah yang sudah memiliki payung hukum jelas, sehingga landasan hukum perbankan syariah dapat setara dengan landasan hukum bank konvensional. Hal tersebut menunjukkan bahwa politik ekonomi Islam dalam ranah keuangan publik Islam telah menunjukkan keberpihakannya pada penerapan keuangan publik Islam secara legal formal. Selain itu eksistensi Lembaga DSN MUI ini merupakan lembaga yang memiliki otoritas kuat dalam penentuan dan penjagaan penerapan prinsip syariah dalam operasional di lembaga keuangan syariah, baik perbankan syariah, asuransi syariah dan lain-lain. Politik hukum ekonomi syariah yang telah dilakukan oleh pemerintah telah memberi dukungan penuh terhadap perkembangan ekonomi syariah di Indonesia. sistem ekonomi Islam dipandang bersifat universal juga karena nilainilai dalam ekonomi syariah itu bisa diterapkan dalam tata kelola keuangan yang baik (Republika, 1 Agustus 2017).

\section{B. Regulasi Ekonomi Syariah di Indonesia}

Regulasi ekonomi syariah diarahkan untuk memberi dukungan yang baik terhadap pertumbuhan dan perkembangan praktik ekonomi syariah. Dalam fungsinya sebagai regulator, pemerintah memfasilitasi upaya pengembangan ekonomi syariah dengan menciptakan lingkungan usaha yang kompetitif dan sehat. Selain itu, penataan regulasi ekonomi syariah dilakukan dalam rangka menyeimbangkan pengawasan dan fasilitas untuk pertumbuhan dan pengembangan ekonomi syariah itu sendiri. Tujuan utama regulasi ekonomi syariah adalah untuk mempertahankan kepercayaan masyarakat terhadap lembaga dan praktik usaha yang berdasar prinsip syariah serta memberi perlindungan kepada pelaku bisnis, nasabah dan lembaga keuangan syariah.

Adapun regulasi ekonomi syariah yang merupakan produk hukum yang mengatur tentang lembaga keuangan ekonomi syariah yang telah terbit adalah:

1. Undang-Undang Nomor 7 Tahun 1992 tentang Perbankan dan Undang-Undang Nomor 10 Tahun 1998 tentang Perbankan

Berdasarkan amanat Musyawarah Nasional Majelis Ulama Indonesia (MUI) pada Agustus 1990 dibentuk kelompok kerja untuk mendirikan bank yang berlandaskan Islam di Indonesia yang akhirnya melahirkan Bank M uamalat Indonesia (BMI) 
di Jakarta. Akta pendirian PT Bank M uamalat Indonesia ditandatangani tanggal 1 November 1991, dan pada tanggal 1 M ei 1992 Bank M uamalat Indonesia sebagai bank syariah pertama mulai beroperasi. Undang-Undang Nomor 7 Tahun 1992 memperkenalkan sistem perbankan yang berlandaskan prinsip bagi hasil. Hal tersebut dilanjutkan dengan lahirnya ketentuan dalam Peraturan Pemerintah Nomor 72 Tahun 1992 tentang Bank Berdasarkan Prinsip Bagi Hasil.

Selain penegasan terhadap eksistensi perbankan Islam di Indonesia, Undang-undang ini juga mengatur kelembagaan dan operasional bank Islam. Sebagai pelaksanaannya dikeluarkan sejumlah ketentuan pelaksanaan dalam bentuk SK Direksi Bank Indonesia yang memberikan landasan hukum yang lebih kuat dan kesempatan yang luas bagi pengembangan perbankan syariah di Indonesia. Beberapa Surat Keputusan Direksi tersebut antara lain sebagai berikut:

a. SK Direksi BI Nomor 32/34/KEP/DIR tanggal 12 M ei 1999 tentang Bank Umum Berdasarkan Prinsip Syariah.

b. SK Direksi BI Nomor 32/36/KEP/DIR tanggal 12 M ei 1999 tentang Bank Perkreditan Rakyat Berdasarkan Prinsip Syariah.

c. Peraturan Bank Indonesia Nomor 6/24/PBI/2004 tanggal 14 Oktober 2004 tentang Bank Umum yang Melaksanakan Kegiatan Usaha Berdasarkan Prinsip Syariah.

d. Peraturan Bank Indonesia Nomor 6/17/PBI/2004 tanggal 1 Juli 2004 tentang Bank Perkreditan Rakyat Berdasarkan Prinsip Syariah.

Berdasarkan Undang-Undang Nomor 23 Tahun 1999 jo. UU Nomor 3 Tahun 2004 tentang Bank Indonesia, maka untuk mengantisipasi perkembangan prinsip syariah, BI mengeluarkan peraturan, antara lain:

a. Peraturan Bank Indonesia (PBI) Nomor 2/4/PBI/2000 tanggal 11 Februari 2000 tentang Kliring bagi Bank Umum Syariah dan Unit Usaha Syariah Bank Umum Konvensional.

b. PBI Nomor 2/7/PBI/2000 tanggal 23 Februari 2000 tentang Giro Wajib M inimum (GWM), PBI Nomor 6/ 21/PBI/2004 tentang Giro Wajib M inimum dalam Rupiah dan Valuta Asing bagi Bank Umum yang Melaksanakan Kegiatan Usaha Berdasarkan Prinsip
Syariah.

c. PBI Nomor $2 / 8 / \mathrm{PBI} / 2000$ tanggal 23 Februari 2000 tentang Pasar Uang Antarbank Berdasarkan Prinsip Syariah

d. PBI Nomor 2/9/PBI/2000 tanggal 23 Februari 2000 tentang Sertifikat Wadi'ah Bank Indonesia.

e. PBI Nomor 5/3/PBI/2003 tanggal 4 Februari 2003 tentang Fasilitas Pembiayaan Jangka Pendek bagi Bank Islam (FPJPS). Undang-Undang Nomor 23 tahun 1999 tentang $\mathrm{BI}$ yang memberi mandat pembentukan bank atau cabang bank syariah.

2. Undang-Undang Nomor 38 Tahun 1999 tentang Pengelolaan Zakat

Regulasi zakat di Indonesia telah dimulai tahun 1968 melalui Peraturan Menteri Agama Nomor 4 Tahun 1968 tentang Pembentukan BAZ di desa/kelurahan dan BAZ Kecamatan sebagai koordinatornya. Dilanjutkan dengan terbitnya SKB dua menteri (M enteri Agama dan Menteri Dalam Negeri) yang mengukuhkan BAZIS dan BAZsebagai lembaga swadaya masyarakat.

3. Undang-Undang Nomor 3 Tahun 2006 tentang Peradilan Agama

Tanggal 21 Februari 2006 Undang-Undang Nomor 7 1989 tentang Peradilan Agama telah diamandemen menjadi Undang-Undang Nomor 3 Tahun 2006 tentang Perubahan atas Undang-Undang Nomor 7 Tahun 1989 tentang Peradilan Agama. Amandemen Undang-Undang Nomor 7 Tahun 1989 tersebut adalah mengenai kompetensi absolut Peradilan Agama mengalami perluasan (extensive) kompetensi absolut (absolutely competence). Dengan perluasan kewenangan ini, lembaga peradilan yang berwenang menyelesaikan sengketa yang berkaitan dengan ekonomi telah menjadi kompetensi absolut Peradilan Agama (PA) yang selama ini dimiliki oleh Peradilan Umum (PN).

4. Undang-Undang Nomor 40 Tahun 2007 tentang Perseroan Terbatas

Undang-Undang Nomor 40 Tahun 2007 mewajibkan kepada setiap perseroan terbatas yang menjalankan kegiatan usaha berdasarkan prinsip syariah mempunyai Dewan Pengawas Syariah (DPS) disamping unsur lainnya. Pasal 109 
Undang-Undang Nomor 40 Tahun 2007 tentang Perseroan terbatas menyebutkan: (1) Perseroan yang menjalankan kegiatan usaha berdasarkan prinsip syariah selain mempunyai dewan komisaris wajib mempunyai Dewan Pengawas Syariah. (2) Dewan Pengawas Syariah sebagaimana yang dimaksud pada ayat (1) terdiri atas seorang ahli syariah atau lebih yang diangkat oleh RUPS atas rekomendasi M ajelis Ulama Indonesia. (3) Dewan Pengawas Syariah bertugas memberi nasehat dan saran kepada direksi serta mengawasi kegiatan usaha perseroan agar sesuai dengan prinsip syariah.

5. Undang-Undang Nomor 21 Tahun 2008 tentang Perbankan Syariah

Kedudukan bank syariah sangat kuat dengan lahirnya Undang-Undang Nomor 21 Tahun 2008 tentang Perbankan Syariah. Sebab, Undang-Undang tersebut tidak hanya menegaskan dual banking system dalam sistem perbankan nasional, tetapi juga menegaskan kesejajaran bank syariah dengan bank konvensional dalam sistem perbankan nasional.

6. Undang-Undang Nomor 19 Tahun 2008 tentang Surat Berharga Syariah Nasional (SBSN)

Tujuan undang-undang ini adalah untuk membiayai Anggaran Pendapatan dan Belanja Negara (APBN) yang selalu defisit, termasuk juga untuk pembiayaan proyek dan infrastruktur. Undang-Undang ini telah menjadi landasan hukum bagi pemerintah RI untuk penerbitan sukuk negara guna menarik dana dari investor.

7. Undang-Undang Nomor 33 Tahun 2014 tentang Jaminan Produk Halal (JPH)

Undang-Undang Nomor 33 tahun 2014 tentang JPH yang diterbitkan pada tanggal 25 September 2014 adalah sejarah penting dalam perlindungan konsumen muslim dalam mengonsumsi produk yang beredar di pasar. Adapun klausula yang sangat penting pada Undang-Undang JPH adalah jaminan terhadap produk yang masuk, beredar, dan diperdagangkan di wilayah Indonesia wajib bersertifikat halal. Saat ini Undang-Undang JPH belum langsung diberlakukan sebab dibutuhkan persiapan keberlakuannya selama lima tahun. Selain itu terdapat beberapa bentuk pengaturan lanjutan sehingga Undang-undang ini dapat diaplikasikan.

8. Undang-Undang Nomor 40 Tahun 2014 tentang Perasuransian

Awalnya, politik hukum asuransi syariah di Indonesia ditandai dengan beberapa Peraturan Menteri Keuangan tentang Asuransi Syariah, antara lain, yaitu:

a. Keputusan M enteri Keuangan Nomor 426/KM K.06/2003 tentang Perizinan Usaha dan Kelembagaan Perusahaan Asuransi dan Perusahaan Reasuransi.

b. Keputusan M enteri Keuangan Nomor 424/KM K.06/2003 tentang Kesehatan Keuangan Perusahaan Asuransi dan Perusahaan Reasuransi.

c. Keputusan Direktur Jenderal Lembaga Keuangan Nomor Kep.4499/LK/2003 tentang Jenis, Penilaian dan Pembatasan Investasi Perusahaan Asuransi dan Perusahaan Reasuransi dengan Sistem Syariah.

Dengan terbitnya Undang-Undang Nomor 40 Tahun 2014 tentang Perasuransian keberadaan asuransi syariah Indonesia telah memiliki landasan hukum yang kuat. Asuransi syariah adalah salah satu bentuk dari dua bentuk asuransi (dual insurance system) di Indonesia yakni asuransi konvensional dan asuransi syariah. Keberadaan asuransi syariah telah terdapat pada Pasal 1 angka 2 yang berbunyi Asuransi Syariah adalah kumpulan perjanjian, yang terdiri atas perjanjian antara perusahaan asuransi dan pemegang polisdalam rangka pengelolaan kontribusi berdasarkan prinsip syariah guna saling menolong dan melindungi.

\section{Realitas Perkembangan Lembaga Keuangan Ekonomi Syariah di Indonesia}

Menurut sejarah keuangan syariah di Indonesia, berdirinya lembaga keuangan berbasis syariah lebih banyak diusahakan oleh kelompok profesional muslim yang lebih berorientasi pada praktik. Namun secara teori keuangan pada umumnya belum terdapat kesepakatan dikalangan akademisi. Kelompok profesional ini merasa tidak perlu menunggu perkembangan teori terlalu jauh. Mereka cenderung mewujudkan fikih muamalat ke dalam praktik, tentu saja setelah dilakukan konseptualisasi. Perkembangan selanjutnya dikawal oleh Dewan Syariah yang dibentuk di 
tingkat nasional maupun di setiap bank dan lembaga keuangan syariah. Jika menilik dari fase perkembangan keuangan Islam di Indonesia, maka kita akan menemui berbagai aturan yang muncul dari inisiatif tokoh agama dan profesional muslim. Berikut fase kemunculan keuangan Islam modern di Indonesia (Pasha, 2017):

a. 1983-1992: rencana terapkan sistem bagi hasil

b. 1992-1998: landasan hukum bank syariah pertama

c. 1998-2010: muncul kebijakan syariah diberbagai sektor

d. 2010-2015: pemantapan kebijakan syariah

e. 2015-2017: digitalisasi keuangan syariah

Untuk lebih memudahkan penilaian dan analisis terhadap perkembangan lembaga keuangan ekonomi syariah, maka data disajikan dalam tiga tahapan periode, sebagai berikut:

1. Periode Pertama (Tahun 1991 - 1999)

Pertumbuhan ekonomi Islam ditandai dengan pendirian bank Islam/bank syariah, maka praktik ekonomi Islam di Indonesia ditandai dengan pendirian Bank Muamalat Indonesia (BMI) pada tahun 1991, yang baru beroperasi pada tahun 1992. Saat Itu belum memakai nama Bank Syariah tetapi sebagai bank bagi hasil, karena belum ada payung hukum yang menjadi naungan berdirinya bank syariah di Indonesia. Dalam kurun waktu mulai dari tahun 1991-1999, perkembangan bank syariah di Indonesia tergolong lambat. Hal ini disebabkan karena tidak didukung oleh aspek perundangan-undangan. Undang-undang yang ada saat ini adalah Undang-Undang Nomor 7 Tahun 1992 tentang Perbankan dan Peraturan Pemerintah (PP) Nomor 72 Tahun 1992 yang merupakan salah satu peraturan pelaksanaan undang-undang tersebut. Dalam Pasal 6 Undang-Undang Nomor 7 Tahun 1992 ditentukan bahwa bank umum dan Bank Perkreditan Rakyat (BPR) yang kegiatannya berasaskan prinsip bagi hasil, tidak diperkenankan melakukan usaha yang tidak berasaskan prinsip bagi hasil. Begitu juga sebaliknya. Ini bermakna, tidak ada peluang untuk membuka Syariah Windows di bank konvensional. Peraturan itu menjadi penghalang bagi berkembangnya bank syariah, karena jalur pertumbuhan bank syariah hanya melalui perluasan kantor bank syariah yang telah ada atau pembukaan bank syariah baru yang membutuhkan dana sangat besar.

2. Periode Kedua (Tahun 2000-2010)

Pada awal periode kedua, perkembangan perbankan syariah belum terlihat secara signifikan. Geliat perkembangan bank syariah terlihat pada akhir periode kedua, yaitu sekitar tahun 2007-2009, di mana terjadi pertumbuhan jaringan

Tabel 1: Jaringan K antor Perbankan Syariah (I Samic B anking Network)

\begin{tabular}{|l|l|l|l|l|l|l|}
\hline \multirow{2}{*}{ KETERANGAN } & \multicolumn{5}{|c|}{ TAHUN } \\
\cline { 2 - 7 } & $\mathbf{2 0 0 5}$ & $\mathbf{2 0 0 6}$ & $\mathbf{2 0 0 7}$ & $\mathbf{2 0 0 8}$ & $\mathbf{2 0 0 9}$ & Jan-10 \\
\hline Bank Umum Syariah : & & & & & & \\
\hline - Jumlah bank & 3 & 3 & 3 & 5 & 6 & 6 \\
\hline - Jumlah kantor & 304 & 349 & 401 & 581 & 711 & 815 \\
\hline Unit Usaha Syariah : & & & & & & \\
\hline - Jumlah bank & 19 & 20 & 26 & 27 & 25 & 25 \\
\hline - Jumlah kantor & 154 & 183 & 196 & 241 & 287 & 268 \\
\hline Bank pembiayaan rakyat syariah: & & & & & & \\
\hline - Jumlah bank & 92 & 105 & 114 & 131 & 138 & 140 \\
\hline - jumlah kantor & 92 & 105 & 185 & 202 & 225 & 263 \\
\hline
\end{tabular}

Sumber: BI, statistik perbankan syariah Januari 2010 
Tabel2: Jaringan K antor Perbankan Syariah (Islamic BankingN etwork)

\begin{tabular}{|l|l|l|l|l|}
\hline \multirow{2}{*}{ KETERANGAN } & \multicolumn{4}{|c|}{ TAHUN } \\
\cline { 2 - 5 } & $\mathbf{2 0 1 4}$ & $\mathbf{2 0 1 5}$ & $\mathbf{2 0 1 6}$ & Jan-2017 \\
\hline Bank Umum Syariah : & & & & \\
\hline - Jumlah bank & 12 & 12 & 13 & 13 \\
\hline - Jumlah kantor & 2.163 & 1.990 & 1.869 & 1.681 \\
\hline Unit Usaha Syariah : & & & & \\
\hline - Jumlah bank & 22 & 22 & 21 & 21 \\
\hline - Jumlah kantor & 320 & 311 & 332 & 285 \\
\hline Bank pembiayaan rakyat syariah: & & & & \\
\hline - Jumlah bank & 163 & 163 & 166 & 166 \\
\hline - jumlah kantor & 439 & 446 & 453 & 451 \\
\hline \multicolumn{2}{|l|}{ Sumber: BI, statistik perbankan syariah Januari 2017} & \\
\hline
\end{tabular}

kantor perbankan syariah yang merambah ke berbagai kota di Indonesia. Pertumbuhan jaringan kantor dapat dilihat pada tabel 1.

Tabel 1 menunjukkan perkembangan perbankan syariah berdasarkan laporan tahunan BI sampai dengan Januari 2010. Secara kuantitas, pencapaian perbankan syariah sungguh membanggakan dan terus mengalami peningkatan dalam jumlah bank. Jika pada tahun 1998 hanya ada satu bankumum syariah dan 76 Bank Perkreditan Rakyat Syariah, maka pada Januari 2010 jumlah bank syariah telah mencapai 31 unit yang terdiri atas 6 bank umum syariah dan 25 unit usaha syariah. Selain itu, jumlah Bank Perkreditan Rakyat Syariah (BPRS) telah mencapai 140 unit pada periode yang sama. Pada lembaga keuangan non bank, Biro Perasuransian Bapepam-LK telah mencatat bahwa pada tahun 2010 telah ada 45 lembaga asuransi syariah yang terdiri dari 42 perusahaan asuransi syariah dan 3 perusahaan re-asuransi syariah. Sedangkan Pegadaian Syariah, perkembangannya di Indonesia tahun ini sudah memasuki tahun ke-8, sejak diluncurkan pada Januari 2003 juga menunjukkan kemajuan yang cukup menggembirakan. Jumlah pembiayaan Pegadaian Syariah sampai akhir Februari 2009, mencapai Rp 1.6 trilyun dengan jumlah nasabah 600 ribu orang dan jumlah kantor cabang sebanyak 120 buah (Ali, 2008: 59).

3. Periode Ketiga (2011-2017)

Perkembangan perbankan syariah terlihat lebih baik pada periode ini, yaitu sekitar Tahun 2013-2017, di mana terjadi pertumbuhan jaringan kantor perbankan syariah yang telah menyebar hampir ke seluruh kabupaten dan kota di Indonesia. Pertumbuhan jaringan kantor dapat dilihat pada tabel2.

Tabel 2 menunjukkan perkembangan perbankan syariah berdasarkan laporan tahunan BI sampai dengan Bulan Januari 2017. Secara kuantitas, pencapaian perbankan syariah terus mengalami peningkatan dalam jumlah bank. sehingga pada Januari 2017 total bank syariah telah mencapai 200 unit yang terdiri atas 13 bank umum syariah dan 21 unit usaha syariah. Selain itu, jumlah bank perkreditan rakyat syariah (BPRS) telah mencapai 166 unit pada periode yang sama.

Berdasarkan data, fakta dan realitas yang telah dikemukakan di atas, terlihat bahwa arah perkembangan ekonomi syariah saat ini menuju ke titik positif. Terutama arah (constituendum) dan kebijakan (policy, beleid) menyangkut hukum ekonomi syariah. Perkembangan tersebut tentunya sangat menggembirakan bagi lembaga keuangan ekonomi syariah. Namun perkembangan ini tidak 
akan berjalan signifikan jika tidak mempunyai dasar dan kebijakan yang mendukung, sehingga target pertumbuhan ekonomi syariah sulit tercapai. Ruang gerak lembaga ekonomi syariah harus dituntun oleh regulasi atau pengaturan yang baik sehingga menciptakan atmosfer pertumbuhan yang baik. Pengaturan hukum yang dimaksud adalah bagaimana pemerintah proaktif dalam melihat perkembangan ekonomi syariah yang sedemikian pesatnya sehingga laju pertumbuhan ekonomi syariah dapat terarah dan mempunyai rel yang pasti. Di sinilah peran politik hukum yang dilakukan oleh pemerintah melalui menciptakan regulasi sebagai checks and balances, seperti membuat kebijakankebijakan yang dapat mendukung kegiatan ekonomi dan pertumbuhan ekonomi syariah baik secara kelembagaan maupun sistimnya agar tetap terarah. Pembangunan ekonomi syariah tersebut diharapkan akan bermuara pada pencapaian kemakmuran yang merata bagi seluruh rakyat Indonesia.

Hukum ekonomi Islam yang lahir di Indonesia setidaknya diawali dari gerakan ekonomi Islam dunia. Sejumlah ulama dan cendekiawan muslim Indonesia mulai melihat fakta bahwa sistem ekonomi kapitalis dan sosialis tidak bisa diharapkan terlalu banyak, karena telah terbukti dampak buruk dari kedua sistem ekonomi ini. M ereka pun berfikir perlu dikembangkannya sistem ekonomi alternatif dari dua sistem ekonomi tersebut. Setidaknya ada dua upaya yang dilakukan, yaitu: pertama, mengkombinasikan dua sistem ekonomi tersebut ke dalam sistem ekonomi baru, seperti yang telah dikembangkan oleh China selama dua dekade ini; kedua, memunculkan sistem ekonomi yang benar-benar berbeda dari semangat kedua sistem ekonomi terdahulu. Ternyata upaya yang kedua di atas yang menjadi pilihan sebagai pintu masuk bagi sistem ekonomi Islam di Indonesia. Pada mulanya pihak-pihak yang meyakini dan memperjuangkan sistem ekonomi Islam sebagai sistem ekonomi alternatif yang berkeadilan dianggap sebagai bahan cemoohan. Sikap optimis bahwa sistem ekonomi Islam dapat menutupi kelemahan dan kekurangan sistem ekonomi kapitalis atau sosialis/ komunis dianggap sebagai ide yang berlebihan dan bahkan dianggap sebagai sebuah pernyataan bombastis-idealistis. Kondisi seperti ini merupakan fakta sejarah yang terjadi di negara-negara Islam, tidak terkecuali di Indonesia. Sampai dengan awal tahun 1990-an cemoohan dan pandangan sinis terhadap pihak-pihak yang gigih memperjuangkan sistem ekonomi syariah masih nyaring terdengar, namun pelan-pelan perjuangan untuk pengakuan sistem ekonomi syariah sebagai sistem ekonomi alternatif mulai diterima (Iswanto, 2013: 85).

Pemerintah Indonesia dipandang telah menempuh langkah penting untuk memperluas pelayanan perbankan untuk mengakomodasi kebutuhan masyarakat muslim, demi meningkatkan partisipasi mereka dalam pembangunan nasional yang bisa dipandang sebagai langkah pencapaian tujuan perkembangan perbankan. Sekitar $87 \%$ dari keseluruhan populasi Indonesia adalah muslim, yang menjadikan mereka sumber sangat berharga untuk pembangunan. Dengan sumber daya potensial yang besar tersebut,akan bermanfaat untuk memperbaiki kesejahteraan masyarakat dan ekonomi secara umum, penting kiranya untuk mengakomodasi aspirasi masyarakat muslim dalam seluruh aspek pembangunan.

Harmonisasi dalam politik hukum ekonomi syariah perlu lebih kuat melalui peraturan keuangan syariah, agar industri keuangan syariah ke depannya akan lebih menunjukkan pertumbuhan lebih signifikan. Regulator harus terus membuat kebijakan yang mendukung pertumbuhan dan perkembanganlembaga keuangan syariah agar tetap berkomitmen secara serius dalam membuat strategi pengembangan. Perkembangan dan pertumbuhan lembaga keuangan ekonomi syariah di Indonesia dapat dikatakan sangat pesat setelah mendapat dukungan pemerintah dalam bentuk regulasi maupun penggunaan instrumen syariah dalam pembiayaan-pembiayaan negara.

Dalam hal lembaga bisnis syariah, perkembangannya di Indonesia juga sangat pesat. Hal ini dapat dilihat dari munculnya berbagai perusahaan pembiayaan yang menawarkan jasa keuangan syariah seperti FIF Syariah, Alljarah Indonesia Finance, dan lain-lain. Dari segi kegiatannya, Industri Keuangan Non-Bank syariah memang tidak memilik perbedaan dengan Industri Keuangan Non-Bank konvensional. Namun terdapat beberapa karakteristik khusus, dengan produk dan mekanisme transaksi yang berdasarkan prinsip syariah. Di antaranya yang dilakukan Lembaga Keuangan Syariah (LKS) berbasis Hukum Syariah yang 
difatwakan Dewan Syariah Nasional M ajelis Ulama Indonesia (DSN MUI), seperti pembiayaan mudharabah (qiradh), pembiayaan musyarakah, pembiayaan ijarah, wakalah, akad mudharabah musyarakah, dan akad kafalah.

\section{KESIM PULAN}

1. Politik hukum ekonomi syariah dalam perkembangan regulasi lembaga keuangan ekonomi syariah di Indonesia. Peran politik hukum terlihat dalam proses positifikasi regulasi ekonomi syariah di Indonesia, dimana pemerintah telah membentuk arah, cara, serta kebijakan dalam memformalkan hukum-hukum yang berkaitan dengan ekonomi syariah di Indonesia. Peran politik hukum yang dilakukan oleh pemerintah melalui menciptakan regulasi sebagai checks and balances, seperti membuat kebijakan-kebijakan yang dapat mendukung kegiatan ekonomi dan pertumbuhan ekonomi syariah baik secara kelembagaan maupun sistemnya agar tetap terarah. Political will pemerintah tersebut mampu mempercepat terwujudnya tatanan ekonomi syariah sebagai sistem ekonomi yang berkeadilan dan menerapkan prinsip-prinsip syariah, sehingga menciptakan atmosfer pertumbuhan yang baik. Indikator tercapainya peran politik hukum ekonomi syariah tersebut ditunjukkan dengan makin banyaknya berdiri lembaga keuangan syariah di Indonesia.

2. Perkembangan lembaga keuangan ekonomi syariah pada periode saat ini terlihat lebih baik dibanding periode sebelumnya. Hal tersebut ditunjukkan dengan telah terjadinya pertumbuhan jaringan kantor perbankan syariah yang telah menyebar hampir ke seluruh kabupaten dan kota di Indonesia. Demikian pula pada lembaga bisnis syariah, perkembangannya sangat pesat dengan dilihat dari munculnya berbagai perusahaan yang menggunakan prinsip syariah, seperti: FIF Syariah, Alljarah Indonesia Finance, dan lain-lain.

\section{DAFTAR PUSTAKA}

\section{B uku}

A fzalurrahman, 1996, M uhammad Sebagai Pedagang, Terj. D ewi N urjulianti, dkk., Jakarta: Yayasan Swarna B humi Ali, Zainuddin., 2008, H ukum Ekonomi Syariah, Jakarka:
Sinar Grafika.

Ali, Zainuddin., 2008, H ukum Perbankan Syariah, Jakarta: Sinar G rafika.

Anshori, A bdul Ghofur., 2008, Penerapan Prinsip Syariah Dalam Lembaga K euangan, Lembaga Pembiayaan dan Perusahaan Pembiayaan. Yogyakarta: Pustaka Pelajar.

H amid, H. M. Arfin., 2006, M embumikan Ekonomi Syariah di Indonesia: Perspektif SosioYuridis. Jakarta: Elsas.

N eil C. Chamelin, et.al., 1975, Introduction to C riminal Justice, Prentice-Hall, New Jersey

M ahfud M D, M oh., 2010, Politik H ukum di Indonesia, cet ke3, Jakarta: Rajawali Pers.

Jurnal dan Laporan

Iswanto, Bambang, Ekonomi Islam Dan Politik Hukum Di Indonesia, Jurnal M azahib Vol XII N omor 2 Desember 2013.

Muhammad, Danang Wahyu., Penerapan Prinsip Syariah Dalam Permodalan Bank Syariah, Jurnal M edia H ukum Vol. 21 Nomor1 Juni 2014

M ashudi, K apitalisme Runtuh Ekonomi Syariah berkah, Jurnal Economica, vol. IV, Edisi 1, M ei 2013

Bank Indonesia, Laporan K euangan Perbankan Syariah Tahun 2010

Bank Indonesia, L aporan K euangan Perbankan Syariah Tahun 2017

\section{Perundang-undangan}

U ndang-U ndang N omor 7 Tahun 1992 tentang Perbankan dan U ndang-U ndang N omor 10 Tahun 1998 tentang Perbankan.

U ndang-U ndang N omor 3 Tahun 2006 Tentang Peradilan A gama

Undang-Undang Nomor 40 Tahun 2007 Tentang Perseroan Terbatas

Undang-U ndang Nomor 21 Tahun 2008 tentang Perbankan Syariah

U ndang-U ndang N omor 19 Tahun 2008 tentang Surat Berharga Syariah N asional (SBSN).

U ndang-U ndang N omor 33 Tahun 2014 tentang Jaminan Produk $\mathrm{H}$ alal (JPH).

Undang-Undang Nomor 40 Tahun 2014 Tentang Perasuransian

\section{Internet}

Kholis, Nur. Potret Politik Ekonomi Islam Di Indonesia Era R eformasi. dalam www.uiiac.id, D iakses pada tanggal 08 Juli 2017. 
Pasha,M uhammad Reksa, Jejak Sejarah K euangan di Indonesia, https:/ / blog.syarq.com/ kemajuan-perbankan-syariahindonesia-898f492916e1, diakses pada 21 Juli 2017.

Republika. M enkeu: Pemerintah Dukung Penuh Ekonomi Syariah. Diakses dari www.republikaonline.com, Jumat, diakses pada tanggal 1 A gustus 2017.

Suhartono. Dinamika Politik H ukum Dalam Kompetensi Pengadi lan A gama. dikutip dari www. badilag.net, diakses pada tanggal 5 Juli 2017. 